\title{
Dynamics of fish diseases in the lower Elbe River
}

\author{
H. Möller \\ Institut für Meereskunde an der Universität; Düsternbrooker Weg 20 , \\ D-2300 Kiel, Federal Republic of Germany
}

\begin{abstract}
As part of a survey on population dynamics and ecology of fishes in the Elbe River, seasonal and regional fluctuations of external fish diseases were studied from the open North Sea to Hamburg in 1981-1982. Clinical signs of 11 different diseases, several of them not being recorded before, were noted in 22 fish species. Averaged over all samples, the total disease prevalence was below $1 \%$ in 16 species. Highest prevalences were found in smelt $(12.7 \%)$, eel $(9.2 \%)$, and flounder $(5.5 \%)$. The frequency of most diseases increased in larger (older) fish. High prevalences of skeletal abnormalities in cod could be related to abnormal migration habits of diseased fish. Spawning papillomatosis, skin ulceration, and fin rot in smelt occurred predominantly during the spawning season. Most diseases observed occurred at relatively high prevalences in the central Elbe estuary between Cuxhaven and Brunsbüttel. This is most obvious for lymphocystis, fin rot, skin ulceration, and bleaching syndrome in flounder, but such a tendency also seems to occur in cauliflower disease of eel, as well as spawning papillomatosis and pharyngeal granuloma in smelt. This area is less heavily polluted and less frequently affected by oxygen deficiency than the area upstream of Glückstadt, where diseases in general occurred at lower frequencies. Therefore, it is concluded that neither pollution nor lack of oxygen are the main triggers for the outbreak of diseases in Elbe fish. It is supposed that large tidal fluctuations of salinity are a major stress factor for fish in the estuary between Cuxhaven and Brunsbüttel. Flounder from this area usually are in a relatively bad nutritional state. Their condition factor increases significantly towards Hamburg, while their disease prevalence decreases in the same direction.
\end{abstract}

\section{INTRODUCTION}

The Elbe is one of the largest rivers in Europe $(1144 \mathrm{~km})$. Intensive stream regulation started in 1840 making it a major inland shipping route. Together with increasing sewage introduction this led to severe conflicts with the use of the river as a source of drinking water and as a fishing area, as reviewed by Riedel-Lorje \& Gaumert (1982).

Complaints of fishermen about decreasing catches have been well documented for more than a hundred years and were accompanied by an intensive reduction of fishing activities during the present century. Wilkens \& Köhler (1977) and Köhler \& Hölzel (1980) have described a retraction of the main fish species of the lower Elbe River since 1950 towards the estuary and attributed this to the effects of increasing channelization and pollution. Möller \& Müller (1984), on the other hand, found no general decrease in the population density of the main fish species when comparing catches per unit effort from fisheries in 1894 and 1982 . However, sale of the main market species - the eel - is practically forbidden, since very high residues of mercury and various chlorinated hydrocarbons have been discovered in its fillets (Krüger \& Kruse, 1982; Kruse et al., 1983). 
Early information on diseases of Elbe fish is scarce. Nieschulz (1921) and Schnakenbeck (1927) described lymphocystis as a well-known and frequently occurring disease of flounder in the Elbe estuary. Cauliflower disease of eel was the main subject of the studies of Lühmann \& Mann (1957), Koops \& Mann (1969), and G. Peters $(1975,1977)$. Several authors have pointed out a possible association between high rates of abnormalities and diseases in Elbe fish and high pollution levels. Wunder (1971) discussed this problem in respect to skeletal abnormalities of cod, N. Peters $(1981 \mathrm{a}, \mathrm{b})$ in respect to gill hyperplasia of flounder and cauliflower disease of eel, and Köhler \& Hölzel (1980), when describing pathological findings of internal organs from smelt and flounder.

During the last $10 \mathrm{yr}$, fish diseases have been used in pollution effects monitoring (Stich et al,, 1977; Sindermann, 1979; Christensen, 1980; N. Peters, 1981a). The evidence for "pollution-associated" fish diseases, however, for many cases is controversial (Möller, 1984). Certain misinterpretations have been made, due to the fact that the level of disease prevalences is dependent upon a variety of mostly unknown factors, environmental as well as stock-specific. Therefore, a statistical correlation between increasing pollution levels and increasing disease frequencies is not sufficient proof for a causal correlation (Möller \& Anders, 1983).

The lower Elbe River is an ideal area for studying this problem. It is reputed for its high pollution levels and well-known for its abundance of fish. Its hydrography and pollution levels have been surveyed intensively by the "Arbeitsgemeinschaft für die Reinhaltung der Elbe" since 1978 (ARGE Elbe, 1980, 1982, 1983). However, only few quantitative data on the occurrence of fish diseases have become available until now.

This paper presents results from the first multi-species survey on fish diseases from the Elbe River and a critical discussion of their correlation to environmental conditions. The present survey was part of a comprehensive study of the biology of Elbe fish, including their species composition, population dynamics, migration habits, parasitation, body condition, food habits, and heavy metal loads (Müller, 1982; Anders, 1983; Fiedler, 1983; Mieth, 1983; Möller, 1983a, b; Wichowski, 1983; Möller \& Müller, 1984).

\section{MATERIAL AND METHODS}

\section{Area investigated}

The fish were sampled by commercial shrimp trawls from September 1981 to September 1982 at Stations 1 to 8, by a young-fish-bottom-trawl from September 1981 to October 1982 at Stations 9 to 17 , and by a commercial anchor net from December 1981 to November 1982 at Stations 22 to 33. Altogether on 102 days of fishing, 319 samples and more than 150,000 individuals were examined. The area of investigation was divided into 8 regions according to Figure 1 . Region $I$ is characterized by a marine fish fauna. The occurrence of freshwater species usually is restricted to Regions IV to VIII. Monthly samples were taken at each station except in January, when all, and in December, when 13 stations had to be ommitted due to ice conditions.

Salinity fluctuated considerably during the survey. The freshwater area was limited downstream to Station 11 in summer and extended to Station 6 during winter (Fig. 2). At Station 1 salinity varied between 16 and $>30 \%$. 
Water depth was between 5 and $10 \mathrm{~m}$, except at Station 17, where it did not exceed $1.5 \mathrm{~m}$. Stations 17 and 31 were located near the mouths of tributary rivers, Station 24 near the nuclear power plant of Brunsbüttel, Station 15 near the nuclear power plant of Stade, and Station 29 near the waste water outlet of the industrial area Bützfleth. The uppermost Station 33 was in the vicinity of the sewage outlet of the city of Hamburg.

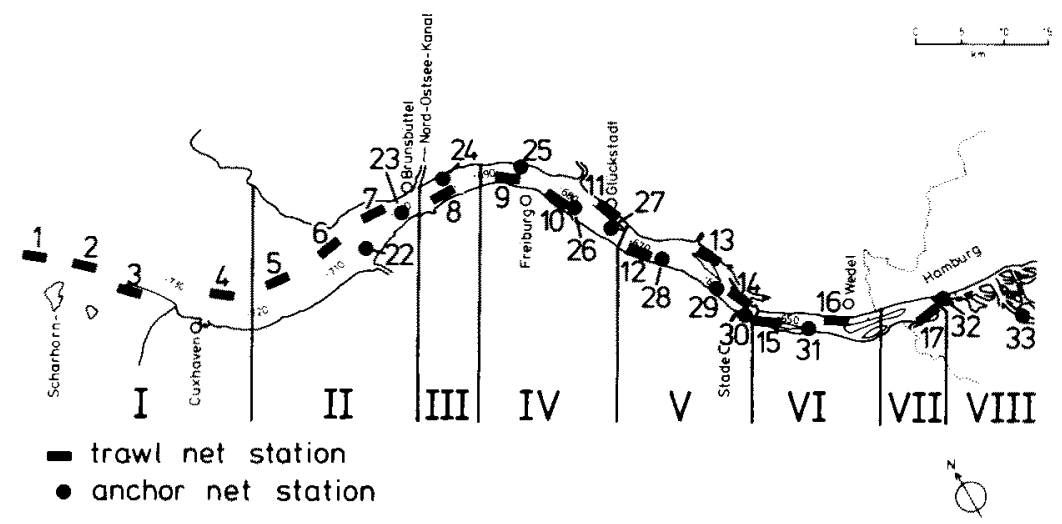

Fig. 1. Station map of fish survey in the lower Elbe River (1981-1982) and location of Regions I to VIII

\section{Fish examination}

Fish were examined macroscopically for externally visible disease signs and abnormalities immediately after capture, except under very stormy conditions, when work was done in the harbour with a delay of up to $3 \mathrm{~h}$. Night samples from Stations 22 to 33 were stored in water tanks and examined in daylight.

Fish were measured on board ship to the $\mathrm{cm}$ below total length. In order to determine condition factors, fish were preserved for at least 2 weeks in $8 \%$ formaldehyde, measured to the $\mathrm{mm}$ below total length and weighed to an accuracy of $0.01 \mathrm{~g}$ after removal of the organs of the body cavity.

All diseases observed during this survey, their probable sources, pathogenicity, and distribution within the Northeast Atlantic Ocean have been described recently (Möller \& Anders, 1983). The only exception is the "bleaching syndrome" of flounder and plaice. Typical signs of this disease include destruction of the mucous layer and of the coloration of the skin, leading to a pale appearance, and progressive fin rot. Diseased fish look as if they had been dead for 2 days; they die rapidly after capture.

Three groups of skeletal deformities have been treated separately: (1) Deformities of the opercula, leading to partial exposure of the gills; (2) deformities of the lower jaw, probably due to damage by hook or net; (3) bull-head and deformities of the spine, including shortening, lordosis, and scoliosis.

Eels were examined for cauliflower disease on head and fins, flatfish for lymphocystis on skin but not on gills. All fish were inspected for papillomas on the skin. The frequency of spawning papillomatosis in smelt might be underestimated, as some of the 


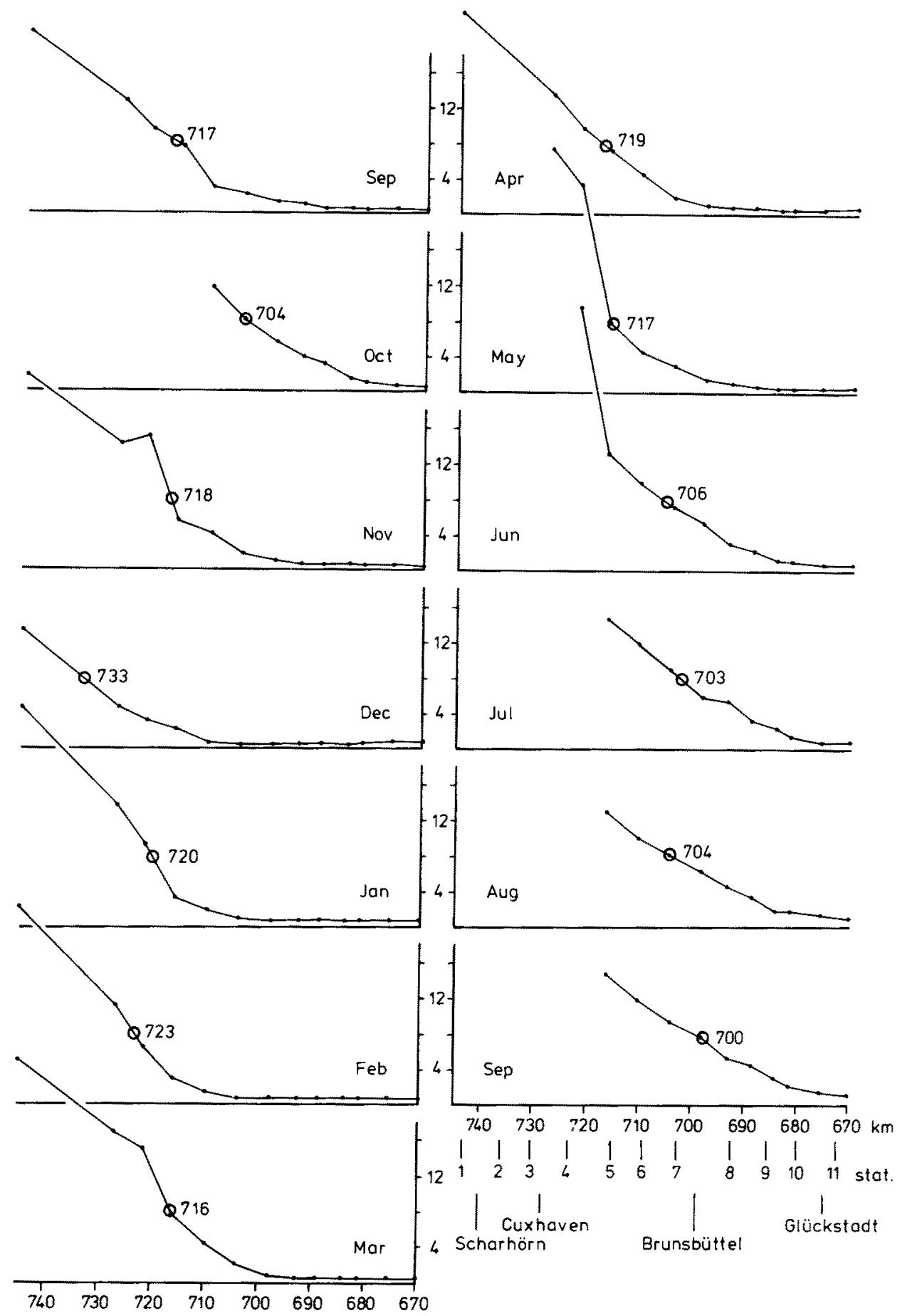

Fig. 2. Monthly and regional fluctuations in salinity $(\%)$ in 0.5 to $1.0 \mathrm{~m}$ water depth, lower Elbe River (1981-1982) calculated from conductivity at low tide. Circles and stream-kilometers indicate the position of the $8 \%$ mark (basic data provided by ARGE Elbe) 
papillomas dropped off easily. A similar observation was made for cauliflower tumors of eel in autumn.

Cod, whiting and smelt were examined for tumors in the gill cavity, smelt additionally for tumors in the mouth cavity. Tumor-like growths in the gill chamber of gadoids, obviously due to previous infestation by Lernaeocera branchialis, were not taken into consideration.

All fish were examined for skin ulceration, fin rot, and eye damage. The occurrence of 2 different diseases in one fish led to a non-significant overestimation of the total disease prevalence in smelt and flounder, as each disease entered a different statistic. Fin rot was not counted in flatfish with bleaching syndrome, as destruction of fin tissue is one of the characteristic clinical signs of the syndrome.

\section{Treatment of data}

In Table 1, the prevalences of 11 different diseases in 22 fish species are listed (averages of all samples). The data give only a rough impression of the disease situation, as neither regional nor seasonal fluctuations or length correlations are considered. In order to reduce the impact of fish length on the data, 0 -group fish were excluded from the calculations by excluding individuals smaller than $12 \mathrm{~cm}$. For species that had been counted but not measured, all specimens of $>4 \mathrm{~cm}$ length were considered. As adult Alosa fallax had been caught in very small numbers, data in Table 1 refer to 0-group shad $(3-12 \mathrm{~cm})$ only.

Diseases that occurred at prevalences above $0.5 \%$ in single fish species were tested for length correlations. A correlation was determined to exist, if its statistical significance exceeded $95 \%$. For each set of diseases, prevalence/fish length data, linear and exponential regressions were calculated. The curve form with the highest correlation coefficient was chosen for further calculations. In cases where correlations were found, disease rates of every $\mathrm{cm}$-group were recalculated according to the statistical relation (for example see Table 2).

To make disease prevalences of different length groups comparable in order to establish regional differences, the data were length-adjusted as described in detail by Möller \& Anders (1983). The percentages of diseased fish of every cm-group were related to the value of the average length group. The length correlation factor for this group was defined as 1 , being $>1$ in $\mathrm{cm}$-groups with lower disease prevalences than in the average group, and $<1$ in $\mathrm{cm}$-groups with higher disease prevalences than in the average cmgroup. For further calculations, the number of diseased fish per length group (i) was multiplied by the length-specific correction factor $\left(c_{i}\right)$. The percentage of diseased fish was then calculated as $\Sigma c_{i} \times$ ( $n$ diseased fish per length group i) $\mathbf{n}$ fish examined. Length groups in which the disease did not occur were excluded from these calculations.

\section{RESULTS}

\section{Smelt (Osmerus eperlanus)}

Smelt are found all over the lower Elbe River. Adult fish aggregate in the estuary in January and February and start their spawning migration upstream in early spring. In 


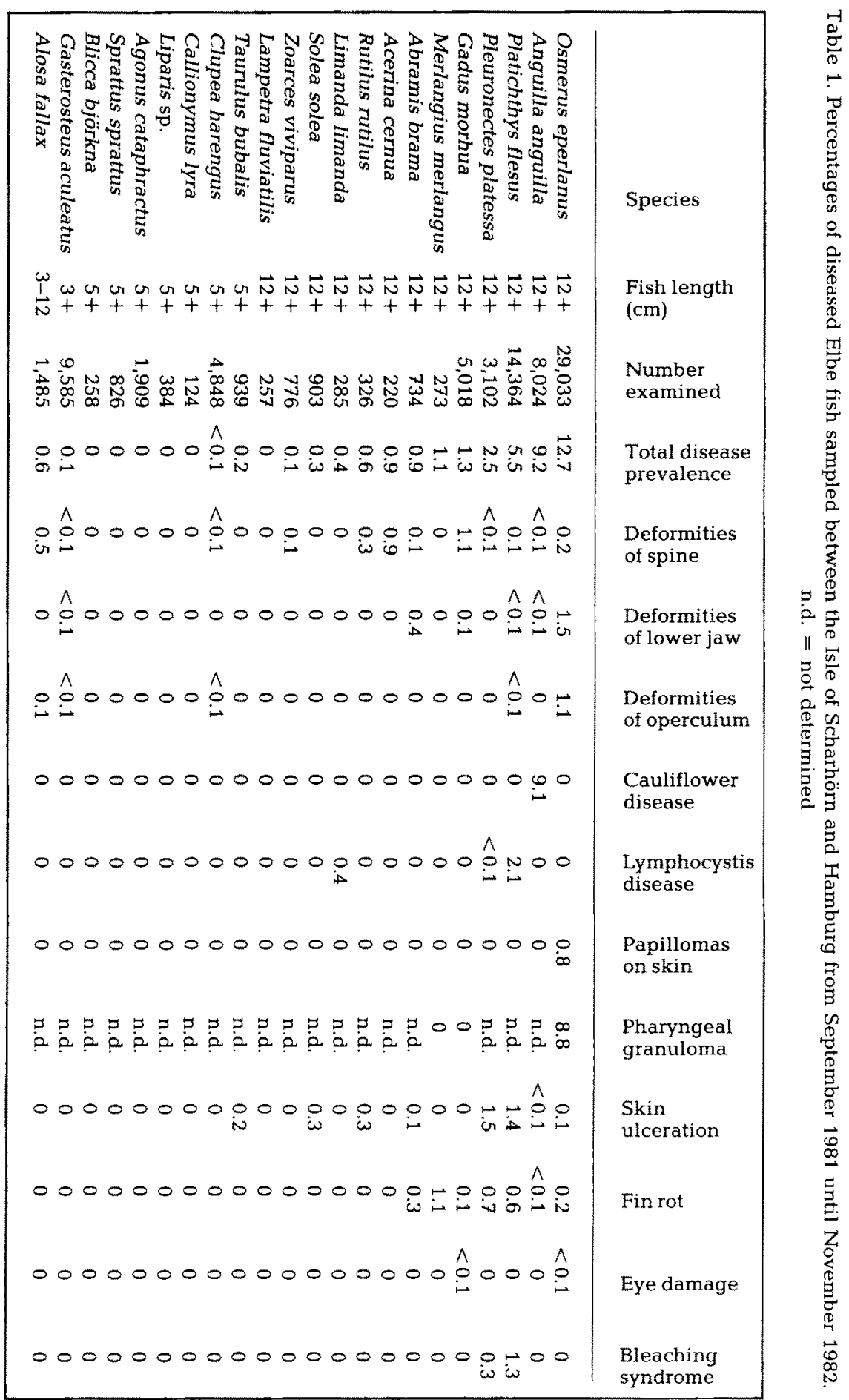


Dynamics of fish diseases

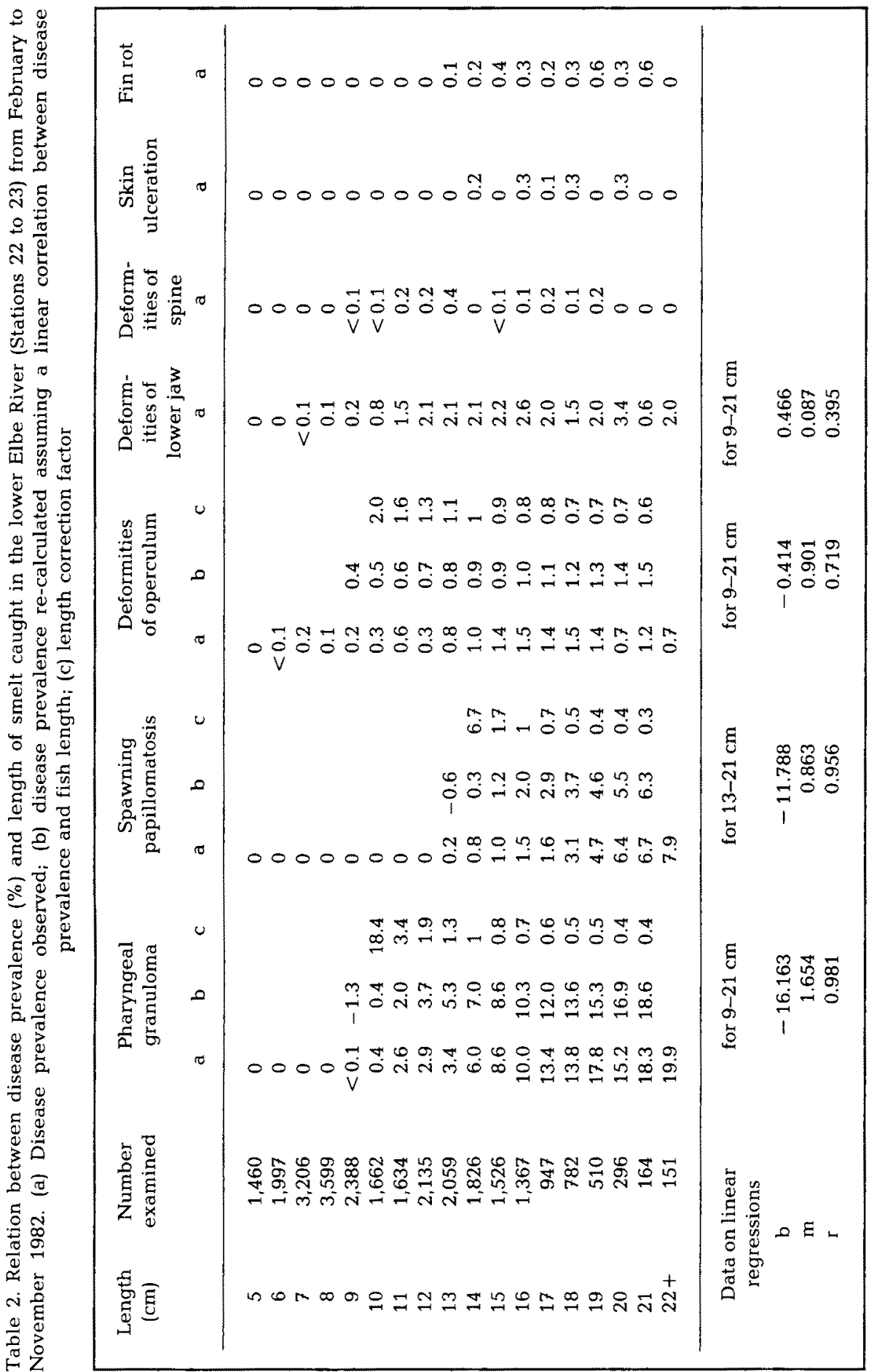


1982, the first 0-group smelt appeared in June, spreading out over the freshwater region by the end of the year (Möller, 1983a).

Smelt was the species with the largest variety of disease signs as well as the highest total disease prevalence (Table 1). Pharyngeal granuloma occurring predominantly on jaws, palate, and inside the opercula, were found in $8.8 \%$ of fish $>11 \mathrm{~cm}$. There was a clear linear relation between disease prevalence and fish length. Approximately $20 \%$ of smelt $>21 \mathrm{~cm}$ carried the disease symptoms (Table 2). The smallest diseased fish measured $9 \mathrm{~cm}$. Monthly disease prevalences increased by a factor of 2.3 from May to September 1982 and were lowest in October 1981 (Table 3). On average during the period of investigation, the percentage of diseased fish decreased from the estuarine Regions II + III towards Regions VII + VIII (Hamburg harbour) from 6.8 to $5.0 \%$ (Table 4).

Spawning papillomatosis was observed exclusively in adult smelt $>11 \mathrm{~cm}$ and only during the spawning period from February to May. The maximum value of $5.5 \%$ for $16 \mathrm{~cm}$ long fish was reached in April 1982 (Table 3). As in pharyngeal granuloma the highest prevalence of this disease was found in Regions II + III.

Externally visible skeletal abnormalities occurred in $2.8 \%$ of adult smelt (Table 1 ). A correlation between disease prevalence and fish length could be established only for deformities of the opercula (Table 2). Higher percentages of deformities were observed in the freshwater area in comparison with estuarine regions (Table 4). No seasonality was evident for the occurrence of deformities of lower jaws and opercula (Table 3).

No regional differences in the prevalences of skin ulceration and fin rot were observed; both occurred in $0.1 \%$ of adult smelt. Highest values were present during the spawning season (Table 3 ).

\section{Eel (Anguilla anguilla)}

Eels were caught in high numbers at most stations upstream of Cuxhaven. Based on the average of all samples and length groups, skeletal anomalies, jaw deformities, skin ulceration (= red pest, Vibrio disease), and fin rot occurred at prevalences below $0.1 \%$. Cauliflower disease was found in $9.1 \%$ of all eel examined (Table 1).

Its abundance is related to season as well as to fish length. During the catch season 1982 , stock eel was affected on average at a rate of $10.0 \%$ and marketable eel at $4.1 \%$ (Table 5, values $<30 \mathrm{n}$ excluded). The highest monthly disease prevalence of marketable eel was $10.1 \%$ in July, dropping considerably during the following months. For stock eel, values near $15 \%$ were observed from August to October (Fig. 3). The length group most frequently affected was 21 to $25 \mathrm{~cm}$. Disease prevalences were less than half this value in eel smaller than $16 \mathrm{~cm}$ and larger than $30 \mathrm{~cm}$ (Table 6).

For regional comparisons, the data were length-adjusted according to the correction factors given in Table 6 and related to the 21 to $25 \mathrm{~cm}$ group. During June and July highest disease prevalences were found in Region $I$, the outer estuary (Table 7). Unfortunately, there are no sufficient data from the following months. Values above $30 \%$ were present in eel from Region III in September and October. This was also the region with the highest average disease prevalence $(14.2 \%)$ from May to September. It was $21 \%$ above the average value of Regions II to VII. 


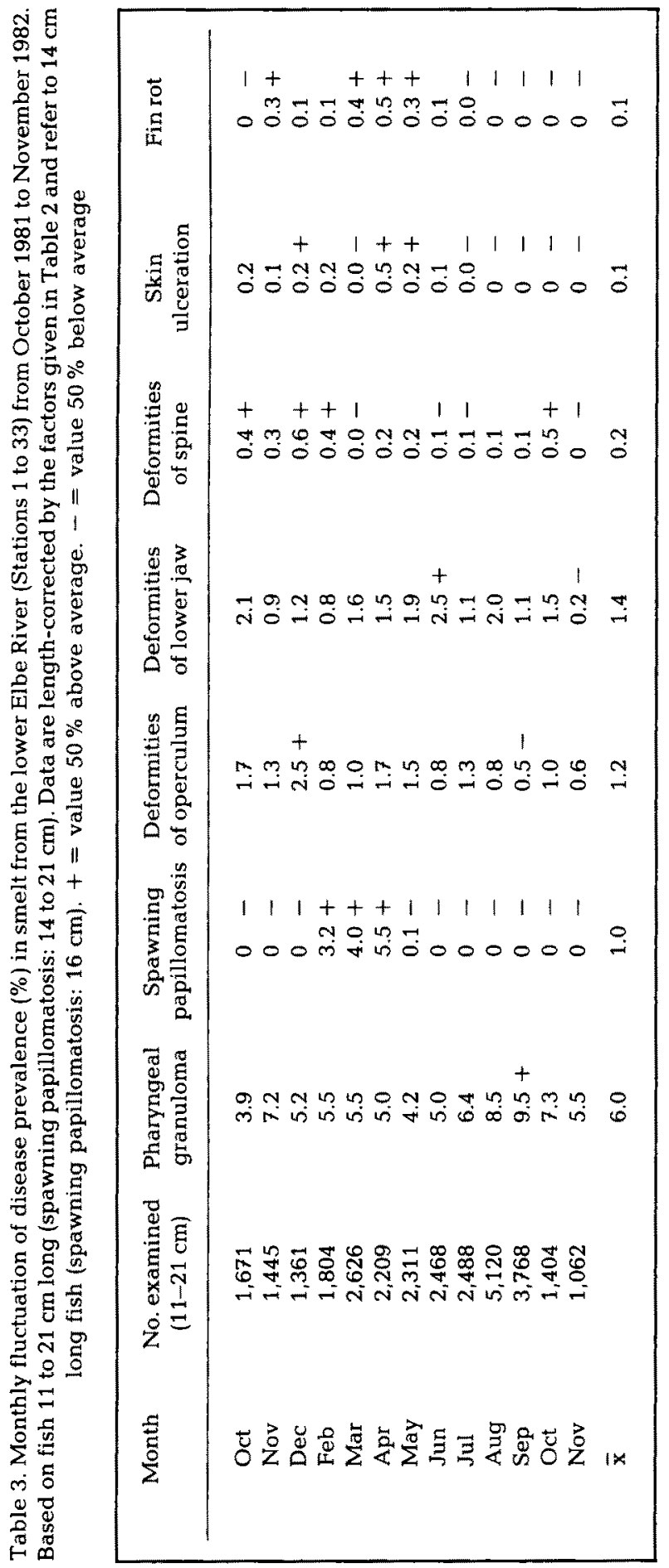




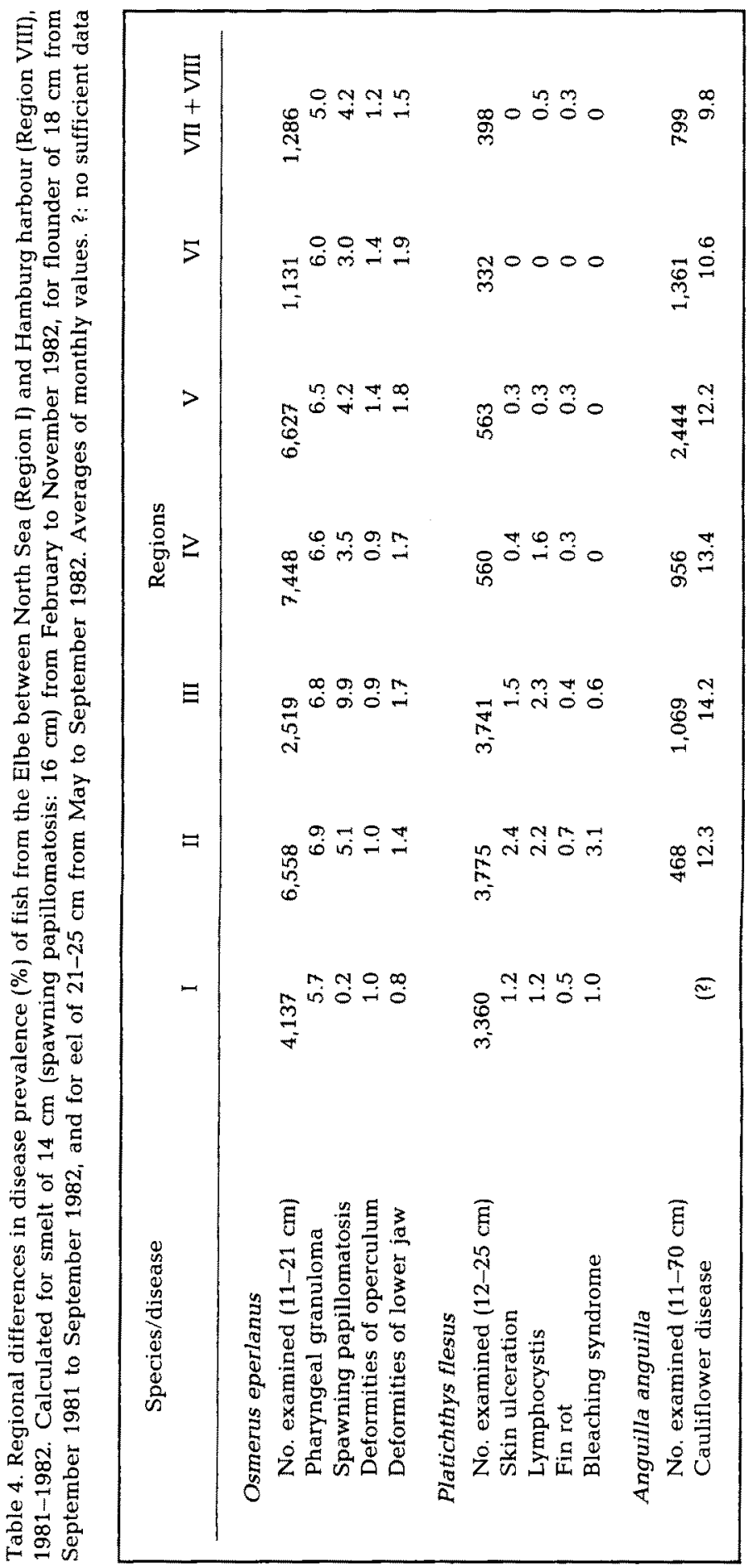




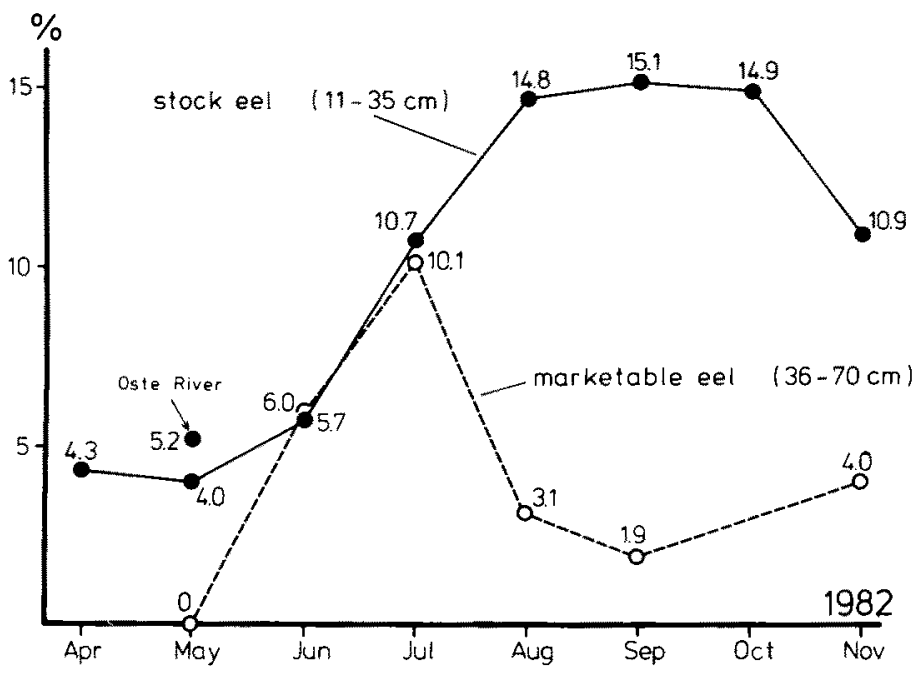

Fig. 3. Monthly fluctuations in the abundance of cauliflower disease in stock eel and marketable eel from the lower Elbe River (Stations 1 to 33) and the Oste River (May only)

\section{Flounder (Platichthys flesus)}

Young-of-the-year flounders in 1982 entered the Elbe in June, remaining in the freshwater region for their first year of life. One-year-old flounders were caught all over the area of investigation, their migration being influenced mainly by ice conditions during winter and lack of oxygen in late summer. Adult flounders were found in large numbers in the estuarine Regions II + III as well as in the Mühlenberger Loch (Station 17) near Hamburg (Möller, 1983a).

Lymphocystis, bleaching syndrome, skin ulceration, and fin rot were the main contributors to a total disease prevalence of $5.5 \%$ on average of all stations in fish $>11 \mathrm{~cm}$ (Table 1). Length correlations of disease frequencies were studied in fish from Stations 5 to 8 caught between September 1981 and September 1982. Except for fin rot, significant correlations were found for all diseases, following a linear regression for skin ulceration and bleaching syndrome and an exponential regression for lymphocystis (Fig. 4). Smallest diseased fish measured $6 \mathrm{~cm}$ for skin ulceration, $8 \mathrm{~cm}$ for fin rot, $9 \mathrm{~cm}$ for bleaching syndrome, and $12 \mathrm{~cm}$ for lymphocystis.

After separation of the age groups according to the length frequency distribution (Moller, 1983a), the development of diseases in one age group could be followed for a period of 12 months. Prevalence of skin ulceration, lymphocystis, and fin rot decreased from November 1981 until April 1982, but increased again during the following months (Table 8).

Data were compiled for regional comparisons of disease prevalences from September 1981 until September 1982 at Stations 1 to 17 . Only fish of 12 to $25 \mathrm{~cm}$ length were included, as smaller fish were not or only seldomly affected and as larger fish occurred only in relatively low numbers. Data in Figure 5 and Table 4 refer to flounders of $18 \mathrm{~cm}$ length. For all diseases examined, the highest percentages were observed in 


\begin{tabular}{|c|c|c|c|}
\hline & 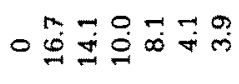 & $\underset{0}{0}$ & $\stackrel{\circ}{+}$ \\
\hline$\dot{z}$ & Nন্ট & $\ddot{d}$ & तु \\
\hline$t$ & 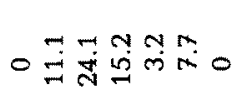 & $\stackrel{?}{\rightarrow}$ & $\frac{0}{5}$ \\
\hline i & 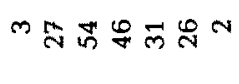 & $\overrightarrow{0}$ & 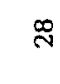 \\
\hline$\frac{20}{2}$ & 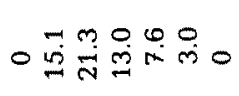 & $\vec{n}$ & $\stackrel{9}{-}$ \\
\hline 完 & 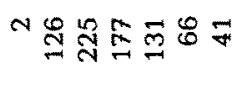 & $\overrightarrow{8}$ & $\stackrel{2}{\circ}$ \\
\hline$g^{\circ}$ & 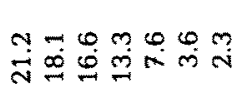 & $\stackrel{\infty}{\underset{\varpi}{+}}$ & $\overrightarrow{\dot{m}}$ \\
\hline ¿ & 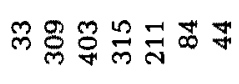 & 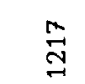 & 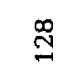 \\
\hline 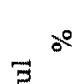 & 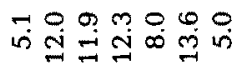 & $\stackrel{x}{0}$ & $\overline{0}$ \\
\hline & 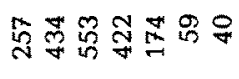 & 雳 & g \\
\hline$\approx 2$ & 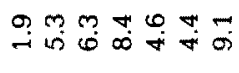 & min & $\stackrel{\circ}{6}$ \\
\hline$\Rightarrow \dot{8}$ & 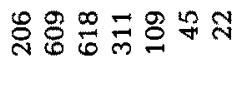 & 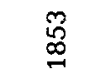 & 8 \\
\hline$\underset{\pi}{2}$ & 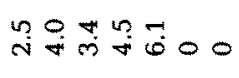 & $\stackrel{9}{*}$ & 0 \\
\hline & 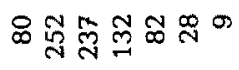 & $\mathscr{\infty}$ & mे \\
\hline$z^{\circ}$ & 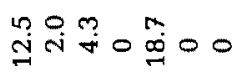 & $\stackrel{m}{+i}$ & อ \\
\hline & $\infty \div 8 \% 0$ & $\overrightarrow{\vec{N}}$ & $\stackrel{\varphi}{\sigma}$ \\
\hline 点 & 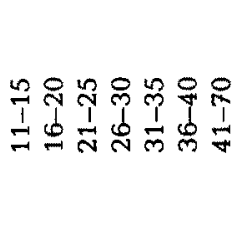 & 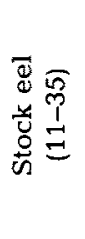 & 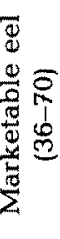 \\
\hline
\end{tabular}


Table 6. Relation between fish length and tumor frequency in eel from Elbe River. Data from June to September 1982 and from Stations 22 to 33

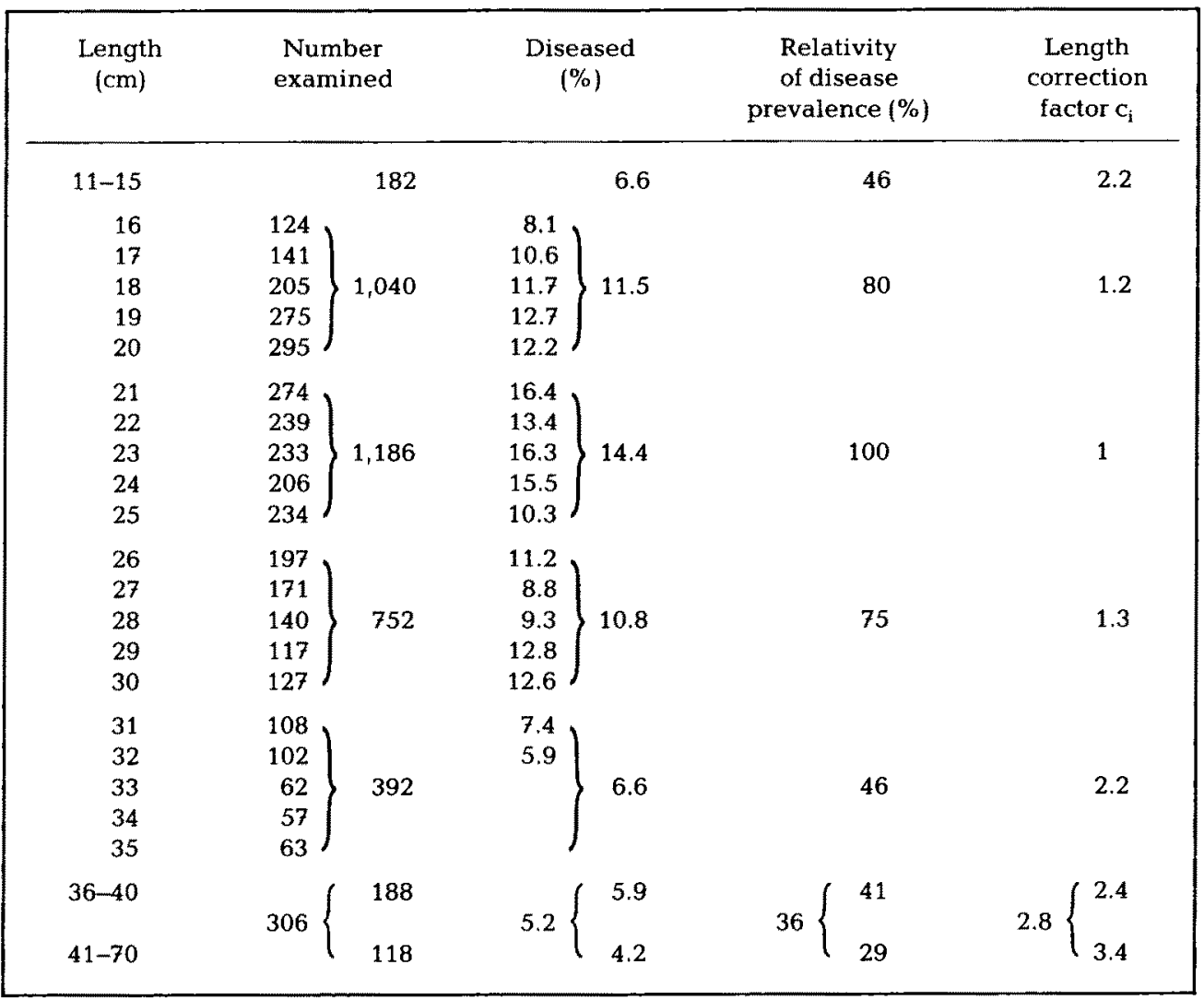

Region II with total values between 7 and $12 \%$ on Stations 5,6 , and 7 . Disease prevalences dropped towards the open North Sea below $1 \%$ for single diseases. Lowest percentages were found in the freshwater area. At Stations 14 to 17, between Stade and Hamburg, only 3 out of $\mathbf{8 1 2}$ flounders were diseased. The total value in Regions V to VII (Glückstadt to Hamburg) was $0.5 \%$ on the average. No flounder with bleaching syndrome was caught upstream of Brunsbüttel.

The presentation of average values masks the fact that occasionally very high disease prevalences can be found. In September 1981, $19 \%$ out of 155 and in October $1981,27 \%$ out of 145 flounders caught at Station 6 suffered from bleaching syndrome. Additionally $6 \%$, and $8 \%$ respectively, carried symptoms of other diseases. In November at the same station values were $9 \%$ for skin ulceration, $13 \%$ for lymphocystis, and $3 \%$ for fin rot (No. $=106$ ).

Seasonal fluctuations of disease prevalences were not as evident as those from other areas. Lymphocystis was most frequently encountered during the spawning season. The maximum value was $3.6 \%$ for $18 \mathrm{~cm}$ long fish from Regions II + III in February (Fig. 6). Fin rot was most abundant during early summer. The 2 highest percentages of skin 


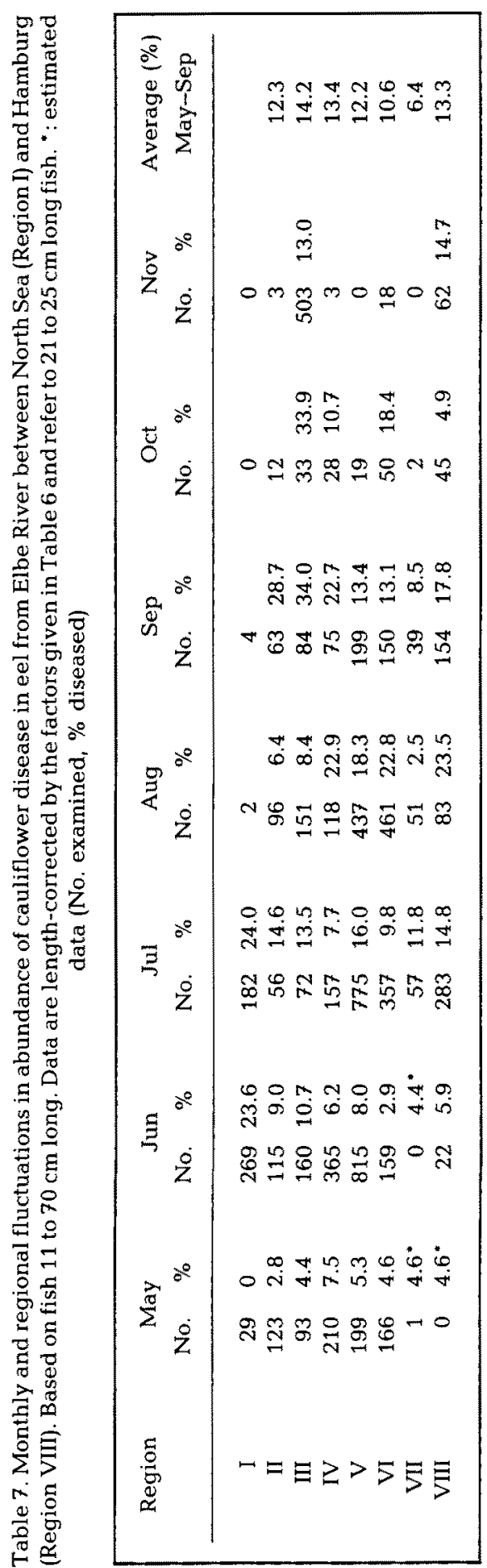


Table 8. Development of disease prevalences in one age group of Elbe flounder from Region II over 1 year

\begin{tabular}{|lccccc|}
\hline Month & $\begin{array}{c}\text { Number } \\
\text { examined }\end{array}$ & $\begin{array}{c}\text { Length } \\
(\mathrm{cm})\end{array}$ & $\begin{array}{c}\text { Disease prevalence (\%) } \\
\text { Skin vilcers }\end{array}$ & Lymphocystis & Fin rot \\
\hline Oct 1981 & 503 & $5-13$ & 0.4 & 0 & 0 \\
Nov & 976 & $5-14$ & 0.7 & 0.2 & 0.1 \\
Feb 1982 & 985 & $5-13$ & 0.3 & 0.1 & 0 \\
Mar & 668 & $5-13$ & 0.1 & 0 & 0 \\
Apr & 107 & $5-15$ & 0 & 0 & 1.5 \\
May & 1,193 & $6-15$ & 0.5 & 0.1 & 0.7 \\
Jun & 443 & $7-16$ & 1.1 & 0.2 & 1.0 \\
Jul & 479 & $9-18$ & 1.9 & 0.8 & 0 \\
Aug & 802 & $11-21$ & 0.6 & 0.5 & 1.3 \\
Sep & 1,076 & $11-21$ & 1.1 & 1.0 & \\
\hline
\end{tabular}
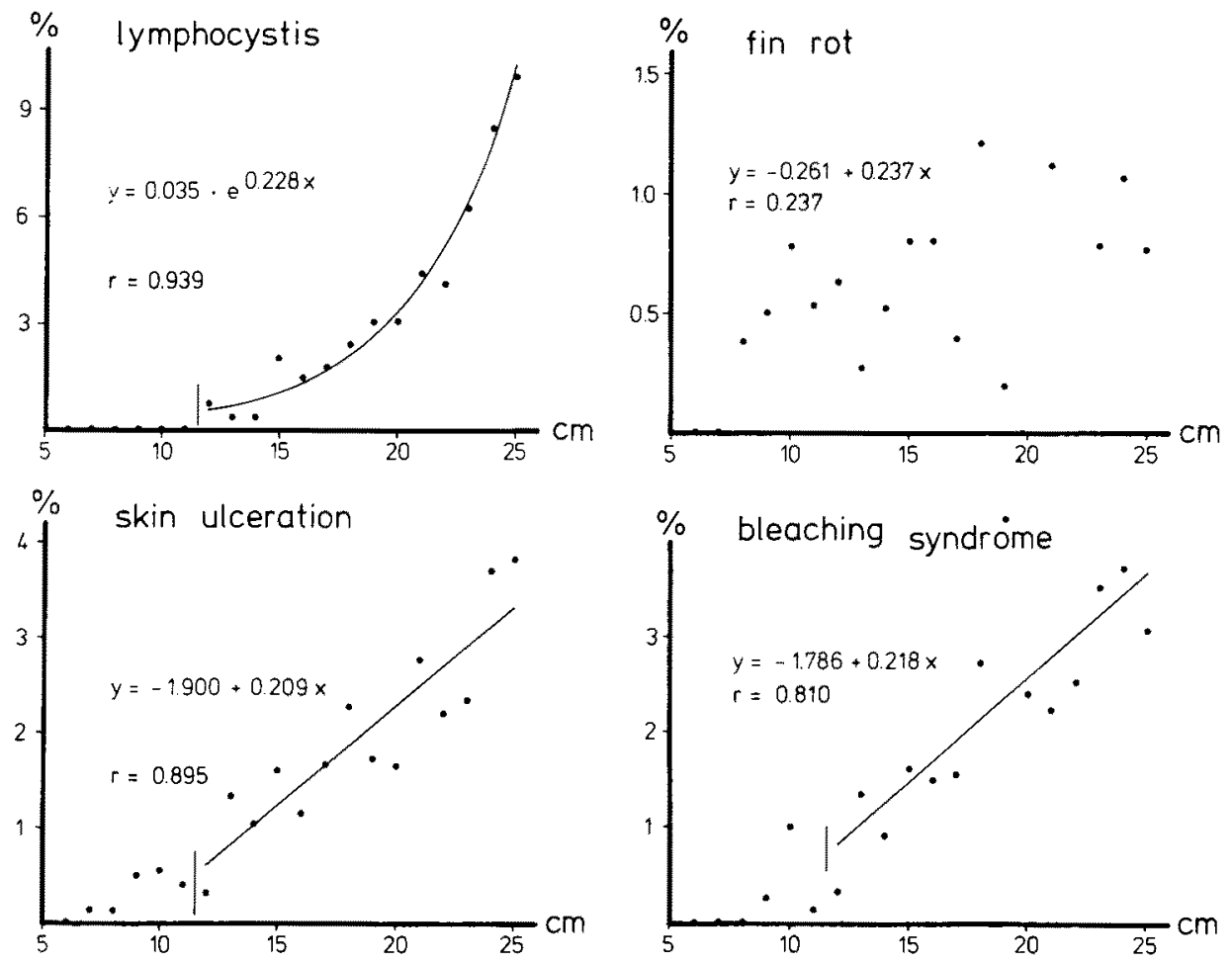

Fig. 4. Relation between average length and disease in flounder from the Elbe estuary (Regions II + III), September 1981 to September 1982

ulceration as well as of bleaching syndrome were found in October 1981. Lymphocystis and skin ulceration were present all year round. Changes in their abundances from one month to the next did not exceed the factor 3 . Very remarkable short-term fluctuations 


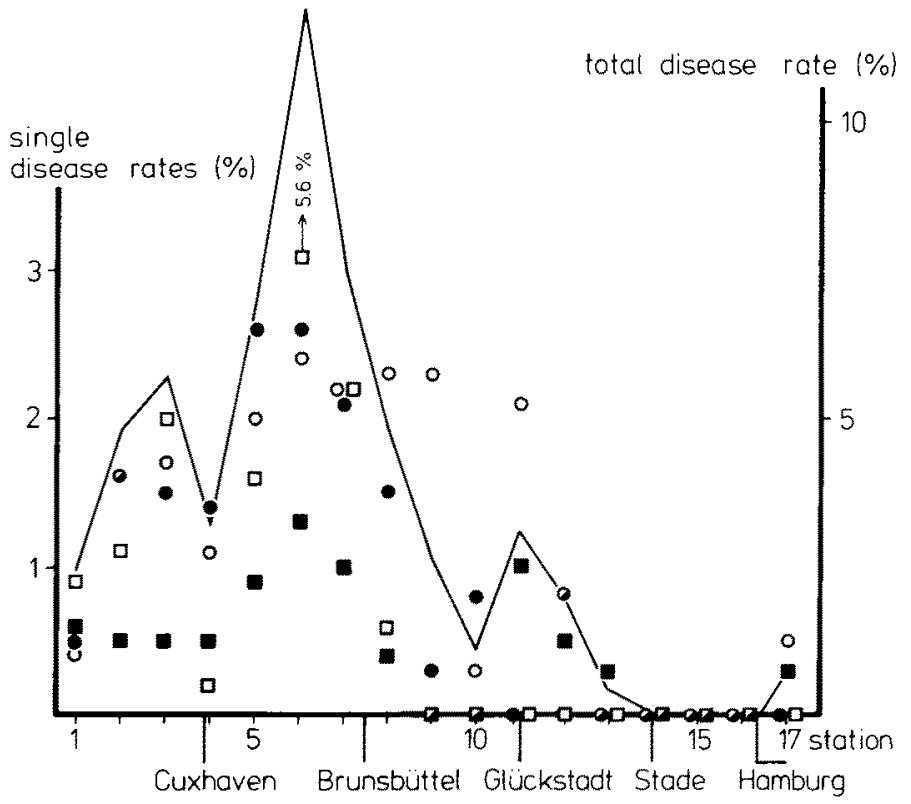

Fig. 5. Regional differences in average disease prevalences of $18 \mathrm{~cm}$ long flounder, September 1981 to September 1982. Open circles: lymphocystis; filled circles: skin ulceration; open squares: bleaching syndrome; filled squares: fin rot; solid line: total disease prevalence

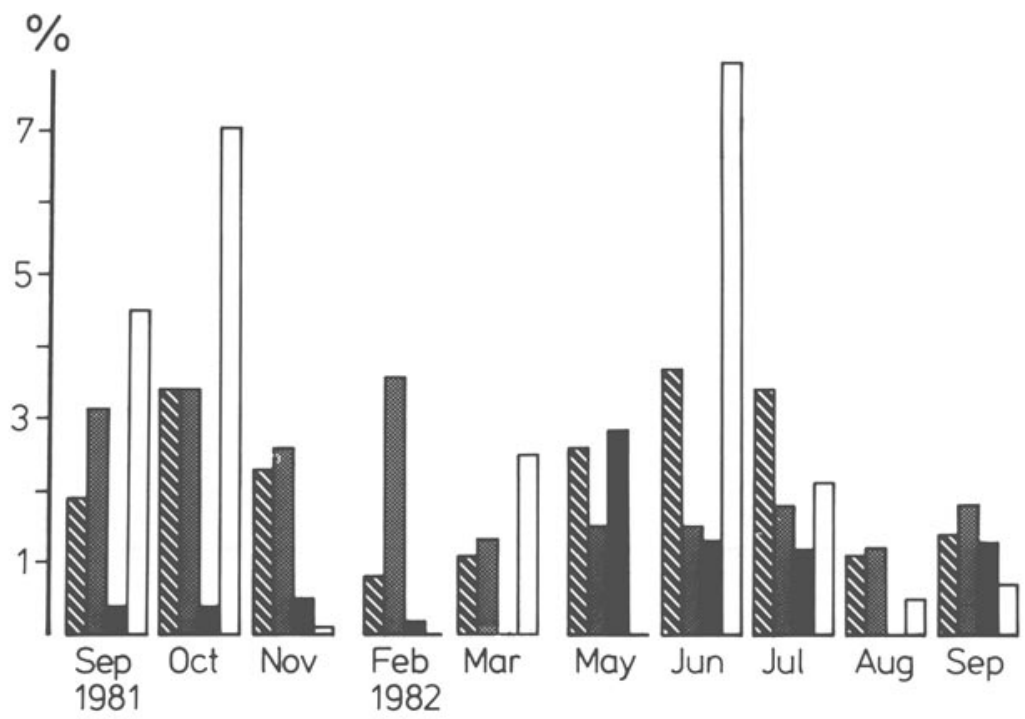

Fig. 6. Monthly fluctuations of disease prevalences in flounder, $18 \mathrm{~cm}$ in length, in the Elbe estuary (Regions II + III). Striped bars: skin ulceration; dotted bars: lymphocystis; black bars: fin rot; white bars: bleaching syndrome 
were evident in fin rot and bleaching syndrome. For both diseases the maximum percentages were reached from a zero level within one or two months (Fig. 6).

\section{Cod (Gadus morhua)}

Within the Elbe estuary, cod migrate upstream to Brunsbüttel (Fig. 1). Skin ulceration, fin rot, and eye damage were observed in $0.1 \%$ or less of the total samples (Table 1). No pseudobranchial tumors were present. Heavy infestation of young cod with Lernaeocera branchialis resulted in reduction of storage fat, and, frequently, in obvious emaciation of the host fish (Müller, 1983).

Various forms of skeletal deformities (shortage and curvature of the spine, bullhead) were found in $0.7 \%$ of $7,752 \mathrm{cod}$ examined (Möller, 1983b). Striking seasonal fluctuations in the disease prevalence are evident from Table 9. In June and July about $50 \%$ of the cod were affected, while the values were between 0.4 and $1.4 \%$ during the rest of the year. These differences were apparently due to abnormal migration habits of deformed fish. Healthy cod usually leave the estuary in summer when water temperature rises, and return in autumn, as indicated by the following. The average catch per unit effort was 270.9 from September to May, but only 1.5 from June to August; the comparative figures for deformed fish were 1.8 and 1.3 , suggesting that the majority of them stay in the estuary the whole year round.

\section{Other fish species}

Among other marine species the total disease prevalence exceeded $1 \%$ only in cod and whiting. Out of 273 individuals, 3 whiting were found to suffer from fin rot in April 1982. No external disease signs were observed in Callionymus lyra, Liparis sp., Agonus cataphractus, and Sprattus sprattus. Among 285 dab Limanda limanda $>11 \mathrm{~cm}$, only 1 diseased individual was found with small lymphocystis nodules. Skin ulceration was the only disease sign in Solea solea and Taurulus bubalis. Skeletal deformities were observed in $0.1 \%$ or less of Zoarces viviparus and Clupea harengus (Table 1).

Table 9. Prevalence of skeletal deformities in cod ( 7 to $20 \mathrm{~cm}$ ) from Stations 1 to 4 in the Elbe estuary (unit haul $=1 \mathrm{~h}$ of fishing with two $11-\mathrm{m}$-shrimp trawls)

\begin{tabular}{|lccc|}
\hline Month & $\begin{array}{c}\text { Healthy fish } \\
\text { per unit haul }\end{array}$ & $\begin{array}{c}\text { Deformed fish } \\
\text { per unit haul }\end{array}$ & $\begin{array}{c}\text { Percentage } \\
\text { of deformities }\end{array}$ \\
\hline Sep 1981 & 621.9 & 2.2 & 0.4 \\
Oct & 422.5 & 1.6 & 0.4 \\
Nov & 400.7 & 1.5 & 0.4 \\
Dec & 206.5 & 1.4 & 0.7 \\
Feb 1982 & 170.5 & 2.5 & 1.4 \\
Mar & 196.8 & 1.5 & 0.8 \\
Apr & 211.9 & 2.6 & 1.2 \\
May & 166.0 & 2.0 & 1.2 \\
Jun & 3.1 & 2.8 & 47.5 \\
Jul & 0.6 & 0.7 & 53.8 \\
Aug & 0.8 & 0.3 & 27.3 \\
Sep & 41.7 & 0.5 & 1.2 \\
\hline
\end{tabular}


Except for smelt, eel, and flounder, in no other freshwater or euryhaline fish species was the total disease prevalence above $1 \%$. Skeletal deformities were observed in Abramis brama, Acerina cernua, Rutilus rutilus, Gasterosteus aculeatus, and in 0-group Alosa fallax; skin ulceration only in Abramis brama and Rutilus rutilus. All Lampetra fluviatilis and Blicca björkna were disease-free.

\section{DISCUSSION}

During the survey in 1981-1982 and during a previous pilot survey (Möller, 1981a) in the lower Elbe River, 3 "new" fish diseases were found: bleaching syndrome, spawning papillomatosis, and pharyngeal granuloma. At least the first 2 have been wellknown to local fishermen for many years. Additional abnormalities are the petechial bleeding in the adipose fin of smelt and in the gill lamellae of various species, a cauliflower-like tumor on the tip of the jaw and tumor-like growth in the adipose fin of smelt (Möller, 1981b). The recent discovery of these frequently occurring and easily recognizable diseases shows that only few systematic studies on the health status of Elbe fish had been carried out before. A similar statement can be made for the population dynamics of fish stocks in the area. On the other hand, public media willingly accept the hypothesis that the occurrence of fish diseases in the Elbe estuary is a result of the relatively high pollution load of the river. A critical review is necessary.

The most spectacular fish disease in the area is the cauliflower tumor of eel. Its source is still unknown. Most probably it is of viral etiology (Möller \& Anders, 1983). Fishery biologists reported this tumor in 1953 for the first time in Elbe eel and noted that it had occurred only very rarely during previous decades, according to information from local fishermen (Lühmann \& Mann, 1957; Mann, 1962).

Koops \& Mann (1969) described an increasing prevalence of cauliflower disease rate from $5.6 \%$ in $1957-1959$ to $11.9 \%$ in 1967 . These data should be regarded with some caution, as the authors were neither able to demonstrate the well established seasonal fluctuations of the disease frequency nor its correlation with host length. G. Peters (1975, $1977)$ continued the survey. The values for the catch seasons 1971-1974 in Table 10 were calculated from her data. N. Peters $(1981 a, b)$ and N. \& G. Peters (1983) described an increase of the prevalence from "up to $6 \%$ in 1955, up to $11 \%$ in 1965 (and 1967) and up to $28 \%$ in the period $1970-1975^{\circ}$. However, they did not cite a report on a very high prevalence in the fifties (19\% in July 1957; Mann, 1962) and compared average values from the whole catch seasons in 1965 and 1967 (Koops \& Mann, 1969) with the value of one single sample in 1971 (28\% in August, No. examined = 100, G. Peters, 1977). Prevalences from the sixties are underestimated, as fishermen had rejected an unknown quantity of diseased eel before examination by scientists (Koops \& Mann, 1969). It remains unclear, to what extent the differences in length of fish examined influenced these data. All authors cited above inspected stock eel of 12 or 15 to $35 \mathrm{~cm}$ length. Within this size group the relative disease frequency varies between 100 and 46 , if 5 -cm groups are taken into consideration (Table 6). According to Table 10, there has been no increase in disease prevalence since the mid-fifties.

The interpretation of regional fluctuations of cauliflower disease prevalences is restricted here to data from Regions II to VIII and May to September (Table 4), due to insufficient data from other months and from Region I (Table 7). The average prevalence 
Table 10. Occurrence of cauliflower disease in eel from the Elbe River 1953-1982. (Data from Peters $[1975,1977]$ are calculated as averages of the catch season, based on monthly average values)

\begin{tabular}{|lccll|}
\hline Year & $\begin{array}{c}\text { Number } \\
\text { examined }\end{array}$ & $\begin{array}{c}\text { Disease } \\
\text { prevalence in } \%\end{array}$ & $\begin{array}{c}\text { Time of } \\
\text { investigation }\end{array}$ & \multicolumn{1}{c|}{ Source } \\
\hline $1953-57$ & $?$ & $<10$ & summer & Mann (1962) \\
1956 & $?$ & 6.8 & summer & Lühmann \& Mann (1957) \\
1957 & 280 & 19 & Jul & Mann (1962) \\
$1957-59$ & 3,416 & 5.6 & Apr-Nov & Koops \& Mann (1969) \\
$1960-63$ & 596 & 8.0 & Apr-Nov & Koops \& Mann (1969) \\
$1964-65$ & 1,070 & 11.1 & Apr-Nov & Koops \& Mann (1969) \\
1967 & 1,432 & 11.9 & Apr-Nov & Koops \& Mann (1969) \\
1971 & 1,200 & 14.8 & Apr-Oct & Peters (1975) \\
1972 & 900 & 8.8 & Apr-Oct & Peters (1975) \\
1973 & 1,200 & 9.8 & Apr-Nov & Peters (1975) \\
1974 & 1,400 & 9.5 & Apr-Oct & Peters (1977) \\
1980 & 204 & 5.9 & Jul & Möller (1981a) \\
1982 & 7,046 & stock eel: & Apr-Nov & Möller \& Anders (1983) \\
1982 & 10.0 & Apr-Nov & Möller \& Anders (1983) \\
& 759 & marketable eel: & Apr-Nov & \\
\hline
\end{tabular}

gradually increases from $9.8 \%$ in Regions VII + VIII to $14.2 \%$ in Region III and decreases to $12.3 \%$ in Region II. However, according to the data available it cannot be excluded that this finding is accidental. These regional distribution patterns could be correlated neither with population density, as indicated by Hussein \& Mills (1982) for eels from Tweed River tributaries, nor with condition factors of eel.

Elbe flounder have recently become the subject of several studies in pathology. Köhler \& Hölzel (1980) described desquamation defects of the intestinal mucosa and lipoid vacuolization of the liver after immigration into the estuary. However, neither "bleaching" of the liver nor the accumulation of lipoids are reliable symptoms of diseased conditions. A whitish coloration of the liver might well be the result of fat storage and "in wild fish at certain times of the year extensive lipid infiltration of the hepatic parenchyma is found and not considered pathological" (Roberts, 1978; p. 219).

N. Peters (1981a) found gill hyperplasia in $54 \%$ of flounders caught during summer in the Elbe estuary and suggested toxic substances as causes of this condition. It seems equally probable that the hyperplasia is a result of an infestation by copepodites of Lernaeocera branchialis. These parasites anchor themselves by cranial filaments into the tips of the gill lamellae. They drop off in summer after their last moult and also when the host enters water of low salinity. The hyperplasia will persist for several weeks (Gercken, 1982; Wichowski, 1983).

The source of the bleaching syndrome of flatfish is still completely unknown. It has been observed in flatfish from the Waddensea (Rauck, pers. comm.) and it is regularly found in adult flounder from Kiel Bight during the spawning season. Neither the presence of pollutants, effects of spawning stress, microbial infections nor damage by nets (rejected by-catch, rejected spawning females) can be excluded as causes of this disease. 
It is remarkable that all 4 flounder diseases (lymphocystis, bleaching syndrome, skin ulceration, fin rot) follow the same trend in their regional distribution patterns. All of them occur most frequently in the estuarine Regions II + III. Their decrease from Region III towards Region I goes along with a decrease of unit catch (No. per hour, age groups 1979-1981) from 891 in Region III to 314 in Region II and 191 in Region I on average from September 1981 to September 1982 (Möller, 1983a). On the other hand, upstream from Region IV towards Region VII the unit catches increase from 211 to 331 , while the disease prevalences drop considerably (Fig. 5).

High population densities, facilitating transmission of pathogens, therefore might contribute to high disease frequencies in the central estuary as compared with the outer estuary. A similar relation between disease prevalence and population density of host fish has also been described for skin ulceration and cod in the German Bight (Möller, 1981a). Low disease prevalences at high flounder densities in the freshwater region of the Elbe might be explained by a marine origin of the causative agents. However, this hypothesis does not explain why they are not replaced by freshwater pathogens.

Pathological studies of Elbe smelt are just beginning (Köhler \& Hölzel, 1980). Spawning papillomatosis seems to be caused by a viral infection (Anders \& Möller, 1984). A similar condition was described by Breslauer (1916) in smelt from waters around Rügen Island in the Baltic Sea. In the pharyngeal granuloma of Elbe smelt we recently found a fungus that is supposed to be the etiological agent of this disease. Deformities of spine and opercula can be induced experimentally by unfavourable water conditions, including pollution, under aquarium conditions (for literature see Möller \& Anders, 1983). Skeletal deformities of fish caught in natural waters usually cannot be attributed to single causative factors, but locally high disease prevalences occasionally can be related to abnormal migration behaviour of the fish (Table 9) or to unfavourable salinities during the larval phase (Berzins, 1943).

In adult smelt, spawning papillomatosis, skin ulceration, and fin rot occur at highest prevalences during the spawning season (Table 3). Pharyngeal granuloma and spawning papillomatosis are more frequently found in the central estuarine Regions II + III rather than in areas upstream or downstream from there. Skeletal deformities do not follow either of these 2 trends (Table 4).

An impact of pollution on the abundance of fish diseases in the Elbe River can theoretically be demonstrated in 3 ways: (1) Along with an increasing pollution level during the last decades increasing disease prevalences might have become evident. (2) Higher disease prevalences might be more evident in fish from the Elbe River than in fish from cleaner areas. (3) Within the Elbe River, relatively high disease prevalences might be evident in regions with relatively high pollution loads.

Unfortunately, regular measurement of Elbe water quality did not start until 1978 and long-term observations on fish diseases have been restricted to cauliflower tumor of eel. Therefore, Way (1) is not suitable.

When comparing disease prevalences of fish from the Elbe with those from other areas, smelt have to be excluded due to lack of any comparable data.

Eel are known to suffer in certain years from a high prevalence of spring ulcer disease (Dalsgaard, 1981) and skin ulceration (= red pest) (Aaser, 1925; Meyer, 1933; Schäperclaus, 1934; Bruun \& Heiberg, 1935; Mattheis, 1960; Wolter, 1960), especially in 
coastal waters of the western Baltic Sea. Both diseases occurred only rarely during the 1982 survey on the Elbe River.

The occurrence of cauliflower disease is restricted to brackish coastal areas of the Baltic Sea, the North Sea, and the Black Sea (Möller \& Anders, 1983). Prevalences of the disease of up to 40 to $50 \%$ have been reported in coastal waters off the German Democratic Republic by Schäperclaus (1953) and southwest Sweden by Thulin (1981). Data comparable to those in the Elbe estuary were reported by Möller (1981a) in the Weser River, and by Hussein \& Mills (1982) in a tributary of the Tweed River, free from toxic wastes.

In flounder from the marine and brackish regions of the Elbe estuary, lymphocystis was found at lower frequencies in comparison with the Irish Sea (Shelton \& Wilson, 1973), Gullmarsfjord (Möller, 1979), Oresund (Nordenberg, 1962), eastern Baltic Sea (Vitinsh \& Baranova, 1976), and Irish coastal waters (McArdle et al., 1982), but at higher prevalences than in Kiel Fjord (Möller, 1974). No sufficient data are available for other flounder diseases.

In other flatfish from the Elbe estuary, disease prevalences were remarkably low. Lymphocystis was found in less than $0.1 \%$ of the plaice examined. Higher values have been reported in many other areas by several authors (Banning, 1971; Perkins et al., 1972; Shelton \& Wilson, 1973; Möller, 1979; McArdle et al., 1982). Among 285 dab $>11 \mathrm{~cm}$, only 1 diseased individual was noted. On the other hand, in summer $1980 \mathrm{on}$ the Dogger Bank in the central North Sea $34 \%$ of dab had skin ulceration, $4 \%$ lymphocystis, and $0.5 \%$ epidermal papillomas (Möller, 1981a). High disease prevalences of dab from other areas have been described by Dethlefsen (1980), Wootten et al. (1982), and Möller \& Anders (1983).

Skin ulceration and fin rot were rare in gadoids from the Elbe estuary in 1981-1982. Differences in size of the fish examined make comparisons with data from other areas difficult. In Kiel Bight $0.3 \%$ of cod 11 to $20 \mathrm{~cm}$ long suffered from skin ulceration between 1971 and 1978 (Möller, 1979). In August 1980, up to $13 \%$ of cod $>16 \mathrm{~cm}$ were diseased at single stations near the island Helgoland (Möller, 1981a). Christensen (1980) described a prevalence of up to $30 \%$ in cod from polluted bays in eastern Denmark.

The total disease rates of 16 other fish species were below $1 \%$, too low to detect any regional differences that might be connected with environmental factors.

Sufficient data are now available to compare regional differences in pollution levels of the Elbe River and in fish disease prevalences in corresponding areas. Among the heavy metals, the main interest is focussed on mercury. When comparing heavy metal loads in muscle of Elbe flounder $(15$ to $17 \mathrm{~cm}$, average of the 3 stations groups 1-4, $8+24,14-16$ and 29-31) with data from other coastal areas, Mieth (1983) found an elevated value only for mercury $(0.42 \mathrm{ppm})$, but not for cadmium $(<0.01 \mathrm{ppm})$, lead $(0.02 \mathrm{ppm})$ or copper $(0.27 \mathrm{ppm})$. No significant regional differences were reported in the mercury load of the Elbe sediment at stations downstream from Hamburg, but values were about 5 to 10 times higher at stations upstream of Hamburg (ARGE Elbe, 1980).

Intensive studies have been carried out on the chlorinated hydrocarbon burden of the Elbe (ARGE Elbe, 1983). It was observed regularly that dieldrin, endrin, DDT, DDD, $\mathrm{DDE}, \mathrm{HCH}_{s} \mathrm{HCB}$, and $\mathrm{PCB}$ occur at significantly higher levels in the sediment upstream of Glückstadt than downstream from there. Also the occurrence of oxygen deficiencies in the water is usually restricted to areas upstream of Glückstadt (ARGE Elbe, 1982). 
Therefore, the general statement can be made that Regions V to VIII in Figure 1 suffer from a higher pollution load than Regions I to IV. What relations are evident in regard to regional differences of fish disease prevalences?

The most striking result of this survey was the discovery that all externally visible diseases supposedly caused by viruses or micro-organisms occur most frequently in Regions II + III in the central Elbe estuary. This is most obvious for lymphocystis, skin ulceration, fin rot, and bleaching syndrome in flounder, but such a tendency also seems to occur in cauliflower disease of eel, and spawning papillomatosis and pharyngeal granuloma of smelt. As highest disease prevalences occur in Elbe regions with relatively low pollution burdens, main triggers for their outbreak other than pollution have to be found.

One of the most obvious stress conditions in Regions II + III is constant tidal change in salinity, ranging from about $2 \%$ to about $15 \%$ in certain localities. In this respect it is interesting to note that high disease prevalences have also been observed in other estuaries. Similar findings were made for flounder diseases in the lower Weser River (Möller, 1981a) and for ulcerations of Oncorhynchus kisutch in an estuary on the Canadian Pacific coast (Wood, cited by Rodgers \& Burke, 1981). Burke \& Rodgers (1981) observed exceptionally high disease prevalences in mullets of a Queensland estuary after heavy rainfalls had led to rapid changes in salinity and temperature. Ulcerative dermal necrosis affects adult Atlantic salmon, usually as they pass river estuaries on their spawning migration (Carbery \& Strickland, 1968).

Further studies have begun to evaluate the ecological significance of continuous changes in salinity for Elbe flounder. Two hypotheses will be examined: The first one suggests that flounders are not sufficiently adapted so that extensive changes in salinity act as stress, reducing the resistence to pathogens. The second hypothesis suggests that changes in salinity affect flounders by destroying their food resources. There is some evidence that a combination of both hypotheses is valid in the case of Elbe flounder.

Fiedler (1983) studied food composition and body condition of Elbe flounder during the same survey. In two different age groups both parameters followed the same trend: stomach contents as well as condition factor were relatively low in the estuarine Regions II + III and increased considerably towards Region VII. Averaged over the year, the condition factor of gutted 15 to $17 \mathrm{~cm}$ long flounder was 1.017 in Regions II + III and 1.098 in Regions VI + VII. It seems quite likely that the very good condition of flounder caught near Hamburg is a major reason for low disease prevalences in that area, while high disease prevalences in the central estuary might have been triggered by weak condition and reduced resistence to pathogens.

Presently available data do not indicate that pollution or lack of oxygen affect the occurrence of externally visible diseases in fish from the lower Elbe River at a measurable level. However, a tidal estuary is a complicated system and it remains unknown to what extent possibly existing pollution effects are masked by more significant effects of various environmental or stock-specific factors. 


\section{LITERATURE CITED}

Aaser, C. S., 1925. Gjeddepesten i 1923. - Norsk VetTidsskr. 37, 1-14.

Anders, K. 1983. Histologische, virologische und statistische Untersuchungen an der Lymphocystiskrankheit von Fischen der Nord- und Ostsee. Dipl.-Arb., Univ. Kiel, 102 pp.

Anders, K. \& Möller, H., 1984. Spawning papillomatosis of smelt (Osmerus eperlanus) from the Elbe estuary. - J. Fish Dis. (in press).

"ARGE Elbe", 1980. Schwermetalldaten der Elbe. Wassergütestelle Elbe, Hamburg, 66 pp.

"ARGE Elbe", 1982. Wassergütedaten der Elbe. Wassergütestelle Elbe, Hamburg, 80 pp.

"ARGE Elbe", 1983. Chlorierte Kohlenwasserstoffe - Daten der Elbe -. Wassergütestelle Elbe, Hamburg, $107 \mathrm{pp}$.

Banning, P. van, 1971. Wratziekte bij platvis. - Visserijwereld 24, 336-343.

Berzins, B., 1943. Über monströse Dorsche im Rigaischen Meerbusen. - Folia zool. hydrobiol. 12, 244-247.

Breslauer, T., 1916. Zur Kenntnis der Epidermoidalgeschwülste von Kaltblütern. Histologische Veränderungen des Integuments und der Mundschleimhaut beim Stint (Osmerus eperlanus L.). - Arch. mikrosk. Anat. EntwMech. 87, 200-264.

Bruun, A. F. \& Heiberg, B., 1935. Weitere Untersuchungen über die Rotseuche des Aales in dänischen Gewässern. - Z. Fisch. 33, 379-382.

Burke, J. \& Rodgers, L., 1981: Identification of pathogenic bacteria associated with the occurrence of "red spot" in sea mullet, Mugil cephalus L., in south-eastern Queensland. - J. Fish Dis. 4, $153-159$.

Carbery, J. T. \& Strickland, K. L., 1968. Ulcerative dermal necrosis (UDN). - Ir. vet. J. 22, 171-175.

Christensen, N. O., 1980. Diseases and anomalies in fish und invertebrates in Danish littoral regions which might be connected with pollution. - Rapp. P.-v. Réun. Cons. int. Explor. Mer 179. $103-109$.

Dalsgaard, I., 1981. Spring ulcer disease in eels. - Bull. Eur. Ass. Fish Pathol. 1, 18-19.

Dethlefsen, $V ., 1980$. Observations on fish diseases in the German Bight and their possible relation to pollution. - Rapp. P.-v. Réun. Cons. int. Explor. Mer 179, 110-117.

Fiedler, M., 1983. Nahrungsuntersuchungen an Elbfischen. Dipl.-Arb, Univ, Kiel, 53 pp.

Gercken, J., 1982. Hyperplastische Epithelwucherungen an der Kieme des Butt (Platichthys flesus) aus dem Elbe-Ästuar. Dipl.-Arb., Univ. Hamburg, 59 pp.

Hussein, S. A. \& Mills, D. H., 1982. The relevance of "cauliflower disease" of the eel, Anguilla anguilla L., in tributaries of the River Tweed, Scotland. - J. Fish Dis. 5, 161-165.

Köhler, A. \& Hölzel, F, 1980. Investigation on health conditions of flounder and smelt in the Elbe estuary, - Helgoländer Meeresunters. 33, 401-414.

Koops, H. \& Mann, H., 1969. Die Blumenkohlkrankheit der Aale. Vorkommen und Verbreitung der Krankheit. - Arch. FischWiss. 20 (Beih.), 5-15.

Krüger, K. E. \& Kruse, R., 1982. Der Quecksilber-, Blei- und Cadmiumgehalt in Aalen aus der Elbe und ausgewähiten Vergleichsgewässern. - Arch. Lebensmittelhyg. 33, 123-128.

Kruse, R., Boek, K. \& Wolf, M., 1983. Der Gehalt an Organochlor-Pestiziden und polychlorierten Biphenylen in Elbaalen. - Arch. Lebensmittelhyg. 34; 81-86.

Lühmann, M. \& Mann, H. 1957: Beobachtungen über die Blumenkohlkrankheit der Aale. - Arch. FischWiss. 7, 229-239,

Mann, H, 1962. Beobachtungen über Krankheiten und Parasiten an Elbfischen. - Fischwirt 12, 300-309.

Mattheis, T., 1960. Das Aalsterben an der Ostseeküste zwischen Usedom und Wismar im Sommer 1959. - Dt. FischZtg., Radebeul 7, 23-25.

McArdle, J., Dunne, T., Parker, M., Martyn, C. \& Rafferty, D., 1982. A survey of diseases of marine flatfish from the east coast of Ireland in 1981. - C. M./ICES, $E 47$.

Meyer, P. F., 1933. Ein Fall von Aal-Rotseuche in den Buchten der Ostsee. - Natur Mus. Frankf. 63, $32-36$.

Mieth, A., 1983. Untersuchungen zum Schwermetallgehalt $(\mathrm{Cd}, \mathrm{Pb}, \mathrm{Cu}, \mathrm{Hg})$ in Flundern, Platichthys flesus (L.) aus der Elbe unter Berücksichtigung jahreszeitlicher Einflüsse. Dipl.-Arb., Univ. Kiel, 93 pp. 
Möller, H., 1974. Untersuchungen über die Parasiten der Flunder (Platichthys flesus L.) in der Kieler Förde. - Ber, dt. wiss. Kommn Meeresforsch. 23, 136-149.

Möller, H., 1979. Geographical distribution of fish diseases in the NE Atlantic. - Meeresforsch. 27, 217-235.

Möller, H., 1981a. Fish diseases in German and Danish coastal waters in summer 1980. - Meeresforsch. 29, 1-16.

Möller, H, 1981b. Feldführer zur Diagnose der Fischkrankheiten und wichtigsten Fischparasiten in Nord- und Ostsee. Field guide to the diagnosis of fish diseases and important fish parasites in North Sea and Baltic Sea. - Ber. Inst. Meeresk. Kiel 86, 1-65.

Möller, H., 1983a. A survey on fish stocks of the lower Elbe River. - C. M./TCES, E 48.

Moller, H., 1983b. High skeletal deformation rate of cod in the Elbe estuary. - Bull. Eur. Ass. Fish Pathol, 3,7-8.

Möller, H, 1984. A critical review on the role of pollution as a cause of fish diseases. Symposium report. First Conference of the European Association of Fish Pathologists (in press).

Möller, H. \& Anders, K., 1983. Krankheiten und Parasiten der Meeresfische. Eigenverl., Kiel, $258 \mathrm{pp}$.

Möller, H. \& Müller, H., 1984. Ein Vergleich von Hamenfischereiertrảgen auf der Unterelbe in den Sommern 1894 und 1982. - Fischwirt (im Druck).

Müller, H., 1982. Biologie, Verbreitung und Schadwirkung auffälliger Ektoparasiten an Fischen der Nordsee und westlichen Ostsee. Dipl--Arb., Univ. Kiel, 90 pp.

Müller, H., 1983. The effects of Lernaeocera-infestation on cod (Gadus morhua). - Bull. Eur. Ass. Fish Pathol. 3, 21-22.

Nieschulz, O., 1921. Die Lymphocystis-Erkrankung der Fische. - Fischerbote 13, $105-107$.

Nordenberg, C. B., 1962. Vorkommen der Lymphocystiskrankheit bei Scholle und Flunder im Oresund. - K. fysiogr. Sällsk. Lund Förh. 32, 17-26.

Perkins, E. J., Gilchrist, J. R. \& Abbott, O. J., 1972. Incidence of epidermal lesions in fish of the north-east Irish Sea area, 1971. - Nature, Lond. 238, 101-103.

Peters, G., 1975. Seasonal fluctuations in the incidence of epidermal papillomas of the European eel Anguilla anguilla L. - J. Fish Biol. 7, 415-422.

Peters, G, 1977. The papillomatosis of the European eel (Anguilla anguilla L.): analysis of seasonal fluctuation in the tumor incidence. - Arch. FischWiss. 27, 251-263.

Peters, N., 1981a. Fischkrankheiten und Gewässerbelastung im Küstenbereich. - Verh. dt. zool. Ges. 74, 16-30.

Peters, N., 1981b. Zur Atiologie epidemisch auftretender Fischtumoren. - Fisch Umwelt 9, 93-109.

Peters, N. \& Peters, G., 1983. Papillomatosis of eels. In: Identification sheets for diseases and parasites of fish and shellfish. Ed. by C. J. Sindermann. ICES, Copenhagen 1983 (Sheet 1), 1-4.

Riedel-Lorje, J, \& Gaumert, T., 1982. 100 Jahre Elbe-Forschung. Hydrobiologische Situation und Fischbestand 1842-1943 unter dem Einfluß von Stromverbau und Sieleinleitungen. - Arch. Hydrobiol. (Suppl.) 61, 317-376.

Roberts, R. J. (Ed.), 1978. Fish pathology. Baillière Tindall, London, $318 \mathrm{pp}$.

Rodgers, L. \& Burke, J., 1981. Seasonal variation in the prevalence of "red spot" disease in estuarine fish with particular reference to the sea mullet, Mugil cephalus L. - J. Fish Dis. 4، $297-307$.

Schäperclaus, W., 1934. Untersuchungen über die Aalseuchen in deutschen Binnen- und Küstengewässern 1930-1933, - Z. Fisch. 32, 191-217.

Schäperclaus, W., 1953. Die Blumenkohlkrankheit der Aale und anderer Fische der Ostsee. - Z. Fisch. 2, 105-124.

Schnackenbeck, H., 1927. "Pockennarbige" Butt. - Fischerbote 19, 81-82.

Shelton, R. G. \& Wilson, K. W., 1973. On the occurrence of lymphocystis with notes on other pathological conditions, in the flatfish stocks of the north-east Irish Sea. - Aquaculture 2 , 395-410.

Sindermann, C. J., 1979. Pollution-associated diseases and abnormalities of fish and shellfish: a review. - Fish. Bull. U. S. 76, 717-749.

Stich, H. F., Acton, A. B., Oishi, K.; Yamazaki, F., Harada, F., Peters, G., Hibino, T. \& Moser, H. G., 1977. Systematic collaborative studies in neoplasms in marine animals as related to the environment. - Ann. N. Y. Acad. Sci. 298, 374-388. 
Thulin, J., 1981. Sjukdomar och parasiter hos fisk vid Bärsebäckverket 1980. Statens Naturvårdsverk, Solna, $31 \mathrm{pp}$. (pm 1429).

Vitinsh, M. \& Baranova, T., 1976. Lymphocystis disease of Baltic flounder (Platichthys flesus L.). - C. M./ICES, $P 6$.

Wichowski, F. J., 1983, Parasitologische Untersuchungen an Elbfischen. Dipl.-Arb. Univ. Kiel, $102 \mathrm{pp}$.

Wilkens, H. \& Köhler, A., 1977. Die Fischfauna der unteren und mittleren Elbe: die genutzten Arten, 1950-1975. - Abh. Verh. naturwiss. Ver. Hamburg 20, 185-222.

Wolter, R., 1960. Die Vibrio-anguillarum-Seuche im Strelasund und Greifswalder Bodden. - Z. Fisch. 9, 763-769.

Wootten, R., McVicar, A. H. \& Smith, J. W., 1982. Some disease conditions of fish in Scottish waters. - C. M./ICES, E 46 .

Wunder, W., 1971. Mißbildungen beim Kabeljau (Gadus morrhua) verursacht durch Wirbelsäulenmißbildung. - Helgoländer wiss. Meeresunters. 22, 201-212. 